\title{
LOW TONE RAISING IN HAUSA: A CRITICAL ASSESSMENT
}

\author{
Paul Newman \\ Indiana University \\ and \\ Philip J. Jaggar \\ School of Oriental and African Studies \\ University of London
}

\begin{abstract}
Low tone raising (LTR) refers to a phonological rule postulated for Hausa by Leben [1971], whereby word-final Low-Low sequences change to Low-High if the final vowel is long. In the first part of the paper, we show that counterexamples to the rule are considerably more numerous and more varied than previously thought. In the second part, we demonstrate that the morphotonemic alternations that served to justify LTR can all be explained by other, better means. We conclude that LTR does not constitute an active, synchronically functioning tone rule in Hausa.
\end{abstract}

\section{Introduction*}

Hausa is a simple two-tone language with Lo, indicated by a grave accent, vs. $\mathrm{Hi}$, left unmarked, e.g. goorà 'cane' vs. gòoraa 'large gourd', makèeraa 'blacksmiths' vs. makeeraa 'smithy'. The language also has a surface falling tone, marked by a circumflex accent, which can be analyzed as $\mathrm{H}+\mathrm{L}$ on a single (heavy) syllable, e.g. bàkán 'the bow' < bàkaa 'bow' + 'n 'the'.

\footnotetext{
* An early version of the first part of this paper was presented at the 14th Conference on African Linguistics, University of Wisconsin, Madison, Spring 1983. The present version was completed while Newman was a fellow at the Center for Advanced Study in the Behavioral Sciences, Stanford, California, with support provided by an NSF grant no. BNS87-00864. For critical comments and suggestions on matters of fact and interpretation, not all of which we have heeded, we are grateful to Sani Sufi Ahmad, Andrew Haruna, Larry Hyman, Muhammed Munkaila, Russell Schuh, and, most especially, Abdullahi Bature.
} 
Given two independent tones, disyllabic words, for example, should manifest four tone patterns: H-H, H-L, L-H, and L-L. It has long been known by Hausaists, however, that $\mathrm{L}-\mathrm{L}$ in the language is quite uncommon, a fact generally accorded no great significance. Leben [1971], however, looked at these words in a new light and came up with some important observations and interesting proposals. To begin with, Leben noted that words with final L-L (whether two or more syllables) not only were uncommon, but also were phonotactically restricted in that they never ended in a long vowel.1 That is, while words such as àbù 'thing', à kwàati 'box', dàgà 'from', gwàdò 'blanket', màcè 'woman', talakà 'commoner', and tùkùn 'yet' are attested, one does not find words such as *bàkàa, *gòoràa, or *makèerà. Leben also noted that there were morphological alternations in which tone and vowel length covaried. For example, trisyllabic verbs belonging to the "grade 1" class end in L-L with a short final vowel before a noun direct object, but L-H with a long final vowel before a pronoun direct object: 2

(1) yaa kar̃àntà littaafí i

'he read a book'

yaa kar̃àntaa shi

'he read it'

To account for the phonotactic gap as well as for the morphophonemic alternations, Leben [1971:202] proposed a rule of Low Tone Raising, henceforth LTR, which stated that if a word ended in a $\mathrm{L}+\mathrm{L}$ sequence, the final $\mathrm{L}$ would raise to $\mathrm{H}$ if and only if the word ended in a long final vowel (henceforth lfv):

(2) Low Tone Raising (LTR)

$$
\begin{gathered}
\text { Lo Lo } \# \rightarrow \\
\text { [+long] }
\end{gathered} \rightarrow \underset{\text { Lo }}{\mathrm{Hi}} \#
$$

Leben did not explicitly discuss the status of the rule, but it was presented as a fully productive, more-or-less exceptionless phonological process rule, comparable to what today one might describe as a post-lexical rule (cf. Kiparsky [1985] and Mohanan [1986]). In other words, LTR was assumed by Leben, and has gen-

\footnotetext{
1Scholars prior to Leben would not have observed correlations between tone and final vowel length since an accurate conception of final vowel length in Hausa was late in developing. For example, both major Hausa dictionaries, Bargery [1934] and Abraham [1962], which in other respects are so outstanding, systematically erred in transcribing all final Lo tone vowels as short (not counting ideophones), thereby missing the important phonemic distinction. The rectification of this error is due primarily to the work of Carnochan [1951, 1952] and Gouffe [1965]. The small dictionary of Newman and Newman [1977] is the first Hausa dictionary to transcribe final vowel length correctly.

2The term "grade" refers to the morphological classification of Hausa verbs presented in Parsons [1960] and now accepted as the reference point by all Hausaists. Modifications to Parsons' system are presented in Newman $[1973,1983]$.
} 
erally been accepted since, to be a synchronically viable rule on the same level as other regular rules in the language, such as the shortening of long vowels in closed syllables or the simplification of LH on a single syllable to H. 3 However, when a larger body of data is taken into account than was originally considered, it turns out that the synchronic status of LTR is far from certain. Our own conclusion is that LTR in Hausa does not function as a regular productive P-rule: it is at best a lexically restricted word formation rule and most probably not a synchronically viable rule at all (see McHugh [1981:17-21]).

Our discussion falls into two sections. First, we present evidence showing that exceptions to LTR are not rare, as had been thought, and that these counter-examples to LTR are too numerous and cover too wide a range of phenomena to be ignored. Then, we scrutinize the alternations that motivated LTR (and which LTR was supposed to explain) and offer alternative analyses which obviate the necessity for LTR and thus undermine much of its justification.

\section{Synchronic Violations of LTR}

Leben [1971:202] states, "Much checking with informants and with sources that mark a long-short distinction on final low-toned vowels ... reveals no word in Hausa which ends in two low-toned syllables, the last of which contains a long vowel." This is apart from the reduplicated words yàayàa = Kàakàa 'how?', which were recognized as non-troublesome exceptions. If one limits oneself to common nouns and verbs out of context, the observation seems to hold. A careful inspection of a wide range of data, however, reveals there are in fact a large number of L-L lfv words that violate LTR. We present eight groups of exceptions.

1.1. Alternative L-L imperatives. Hausa has a small set of (monotonal) $\mathrm{H}-\mathrm{H}$ verbs ending in /aa/, namely biyaa 'pay', kiraa 'call', jiraa 'wait for', rigaa 'precede in doing'. In the imperative, they take the normal L-H imperative tone pattern, e.g. biyaa! 'pay!', cf. tsàyaa! 'stop!' < tsayàa 'stop'. The L-H pattern is also the norm when the verb is followed by a noun direct object; but, as discovered by Jaggar [1982], there is for some speakers a tonal alternative. Instead of using $\mathrm{L}-\mathrm{H}$, the force of the imperative can be modified by pronouncing the verb L-L. 4 The result is a L-L lfv verb form that does not obey LTR, e.g.

${ }^{3} \mathrm{HL}$ on a single syllable is realized on the surface as a falling tone. Hausa does not have corresponding rising tones because $\mathrm{LH}$ on a single syllable automatically simplifies to $\mathrm{H}$ in accordance with a rule first pointed out by Parsons [1955] and discussed more fully by Leben [1971]. In considering the presumed phonological status of LTR, one should note that Leben presented it in exactly the same terms as he presented the LH to $\mathrm{H}$ rule, which is indeed a synchronically exceptionless process rule.

${ }^{4}$ For a full discussion of the semantic/stylistic content of the alternative imperative form, see Jaggar [1982]. 
(3) bìyàa kudîn!

ji ràamitumin!

kiràa Saani! 'pay the money!' (cf. the usual biyaa kudin!)

'wait for the man!' (cf. jiraa mutumin!)

'call Sani!' (cf. kiraa Saani!)

Jaggar's (1982) study of the imperative was confined to "monoverbs" (= monosyllabic CV verbs) and the few disyllabic monotonal verbs exemplified in (3); thus the LTR violations were hardly numerous. It turns out, howeverand this is something that to our knowledge has never been described beforethat alternative L-L imperatives also exist, and in fact are quite common, with a range of verb grades and forms when followed by noun indirect objects, e.g. 5

(4) ràbàa wà mutàanên kudîn!

'distribute the money to the people!'

(= rabaa wà ...); cf. the verb with an indirect object pronoun: ràbaa musù kưín! 'distribute the money to them!', not * ràbàa musù ...)

kàràntàa wà Saanilittaafi n!

'read the book to Sani!'

$$
\text { (= kàràntaa wà ...) }
$$

mimmi ikàa wà bàkii mintìi! 'offer the guests mints!'

(cf. mimmiikaa musù ... 'offer them ...')

kàshèe wà yáaraa fi tilàa!

'put the light out for the children!'

(= kàshee wà ...)

gùtsùròo wà bàakii tuwoo!

(= gùtsùroo wà ...)

'break off some tuwo for the guests!'

jàjjàa wà mutàanee ruwaa à riiji yaa! 'draw water for people at the well!' (cf. the verb followed immediately by a direct object: jajjaa mutàanên ciki! 'pull the men inside!', not *jàjjàa mutàanén ciki)

5 The $=$ sign in the examples indicates essentially equivalent, equally grammatical forms. As described for monotonal verbs by Jaggar [1982], the L-L and L-H imperatives differ slightly in nuance with regard to the strength, politeness, etc. of the command. Since the indirect object (i.o.) marker $\mathrm{wa}(=\mathrm{ma})$ tends to attach to the preceding verb, as has been observed by a number of scholars, one might object that these $\mathrm{L}-\mathrm{L}$ imperatives do not really constitute violations of LTR, i.e. karanta 2 wa 'read to ...' should be interpreted as karantala-wa, in which case the verb-final L-L lfv would not be word final. However, as LTR is generally applied, it is essential that there be a word break between the verb and the i.o. marker so as to account for verb tones in declarative sentences and in the better known L-H imperatives. For example, in yaa karantaa wa Saani littaafi $n$ 'he read the book to Sani', the final H-L-H tone of katantaa is supposed to have come from H-L-L by means of LTR. The pre-i.o. verb forms thus constitute an embarrassment to LTR whichever way one decides to analyze the degree of bonding between the verb and the i.o. marker. 
1.2. Plurals of augmentative adjectives. Hausa has an interesting set of descriptive adjectives referred to as "augmentative adjectival-nouns" [Parsons 1963], "profusatifs" [Mijinguini 1986], or "augmentative adjectives" [R. Newman 1988]. In one of its variants - these words exhibit several alternative patternsthe masculine singular is characterized by a suffix -eeCee and a $\mathrm{H}-\mathrm{L}$ tone pattern while the feminine is formed therefrom by adding -iyaa, e.g. 'broad' fankameemè (m), fankameemiyaa (f). The corresponding plural is a $\mathrm{H}-\mathrm{L}$ reduplicated form with long final/aa/, e.g.

(5) fankamaa-fànkàmàa pl. of fankameemèe/fankameemiyaa 'broad'
zabgaa-zàbgàa
pl. of zabgeegèe/zabgeegi yaa
'tall and beautiful'
'expansive'
makkaa-màakàa
pl. of maakeekèe/maakeeki yaa
fir̃óa-fĩ roda
pl. of fir̂́feedèe/fir̂́feedì yaa
santalaa-sàntàlàa
pl. of santaleelèe/santaleeliyaa
'huge (e.g. horses)'
'thin, svelte'

While these words are semantically expressive, 7 there is nothing so totally aberrant about them that would allow one to casually disregard them as LTR exceptions. Parsons [1963:195], for example, comments that "though highly phonaesthetic, [augmentative adjectives] are quite systematic in their phonology", by which he means that they obey normal rules and phonotactic restrictions affecting consonants and vowels. From the point of view of their morphosyntax, augmentatives behave essentially like other adjectival nouns: they may occur either before or after the noun they modify and if before, they require the use of a genitival linker; they agree in number and gender with the head noun; and they may be used without an expressed noun, e.g.

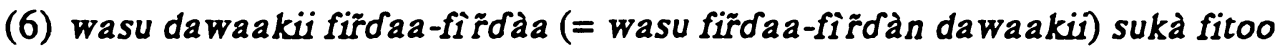

'some huge horses came out'

cf. wani dookì i fiřdee dèe (=wani fiřrdee dèn dookì) ya fitoo

'a huge horse came out'

6The verb baa (= baa before pronoun objects) is often described as taking double direct objects. However, the imperative form bàbbà of the reduplicated "pluractional" would support the claim that the object following the verb is really an indirect object and that the pre-noun marker wa is not syntactically absent, as has generally been thought, but rather is phonologically fused into the verb baa. Thus, the sequence bàbbàa mutaanen 'give the men!' is syntactically parallel to jajjàa wà mutaanen 'pull for the men!' (with the overt indirect object marker) and not to jajjaa muta anen 'pull the men!'.

7In translating these words Parsons [1963] uses expressions such as 'whacking big', 'smashingly beautiful', etc. to capture their emotive and stylistic power. 
yaa kalli maataa zabgaa-zabgàa 'he looked at the tall, beautiful women', cf. yaa kalli màcè zabgeegi yaa 'he looked at the tall, beautiful woman' naa ga wasu buulaa-6ùulàa cf. the non-augmentative naa ga wasu sàababbii 'I saw some new ones'

1.3. Ideophonic adjectives. Apart from the plural augmentatives, there are many other reduplicated adjectives with final L-L and a long final vowel, some of which are quite common. These are usually classed as ideophones, but morphosyntactically they, too, behave in a manner similar to other adjectives, ${ }^{8}$ e.g.

(7) daraa-dàràa 'bulging'

as in tanàa dà idòo daraa-dàràa

'she has bulging eyes'

zaraa-zàràa 'long and thin'

as in tanàa dà zaraa-zàràn 'yan yaatsuu

'she has long, thin fingers'

6aloo-6à1òo 'large and round'

as in taa baa ni gooŕo baloo-6àlòo

Fabee-rábèe 'pendulous'

as in tanàa dà noondo rabee-r̃àbèe

buzuu-bùzùu 'hairy'

as in geemùnsà buzuu-bùzùu yakè

'she gave me some good (large and round) kolanuts'

'she has pendulous breasts'

'his beard was disheveled'

1.4. Ideophonic adverbs. Phonologically parallel to the ideophonic adjectives but syntactically distinct from them are the reduplicated ideophonic adverbs of manner. ${ }^{9}$ This class includes not only semantically marked expressive ideophones but also words that native Hausa speakers now treat as ordinary adverbs, 10 e.g.

\footnotetext{
${ }^{8}$ These ideophonic reduplicated adjectives differ from ordinary "adjectives" in that they do not inflect for number or gender, nor can they occur as independent nominals.

${ }^{9}$ While we have chosen our examples from regular reduplicated patterns, it should be pointed out that non-reduplicated ideophones ending in L-L and a lfv are also not uncommon, e.g. rijża 'suddenly', as in yaa faadi ri jàa 'he suddenly fell down'; bòodoo 'large', as in yanda dà hancii bododðo 'he has a large nose'; rabajà 'spread out', as in yaa yi rabajala da shii 'he lay down spread out (e.g. from exhaustion)'.

10 In Hausa the distinction between ideophones, which are generally regarded as extra-systemic, and adverbs of manner is not so clear-cut. Forms such as 6aroo-6ardo 'clearly, unequivocally' or jina a-jì nà a 'bloodied' (< jinii 'blood') which would normally be classified as ideophonic on the basis of their canonical shape, appear more like normal adverbs in that (a) they are semantically more generalized and less emotive than typical ideophones and (b) they are pronounced without the marked expressive intonation normally associated with ideophones.
} 
(8) Garoo-6àròo 'clearly, unequivocally'

as in sun fà di làabaañii baroo-bàròo

jagee-jàgèe 'abundant'

as in naa ga àbinci jagee-jàgèe

dagajee-dàgàjèe 'in a bad condition'

as in naa gan shì yaa tahoo dagajee-dàgàjèe 'I saw him come in a sorry state' dumuu-dùmùu 'messy'

as in bàakinsà yaa yi dumuu-dùm ùu dà mâi 'his mouth was messy with oil'

Kirii-kirii 'in the open'

as in an kaamàa shi Kirii-kirii

jinaa-jìnàa 'bloodied'

as in sun yi jinaa-jì nàa 'they told the news in unequivocal terms'

'I saw a mass of food'

1.5. Ideophonic action nouns. A small number of reduplicated words with final L-L and a long final vowel are nominals that denote some kind of action or state. These words often have corresponding "frequentative dynamic nouns" [Parsons 1963:188n] formed with the suffix -niyaa, e.g.

(9) mun yi rabaa-ràbàa

(< rabàa 'to separate')

'we have quarreled and split up'

tanàa wacaa-wàcàa (= wàcàaniyaa) dà kudintà 'she is squandering her money' sun yi wukii-wùkii (= wùkìiniyaa) dà idòo sai kà cée bàraawòo 'they are looking guilty/ashamed like they're thieves'

sunàa hàyàa-hàyàa (hàyàaniyaa) 'they are bustling about chattering'

tsiyaa-tsi yàa mukà yi dà shii 'we had a vituperous argument'

One should emphasize that while these words are phonologically distinctive in having a set reduplicative pattern, there is nothing lexically aberrant or peculiar about them. They are most often used immediately following the verb $y i$ 'do' (which is generally deleted in the continuative tenses), but they have other syntactic possibilities as well, e.g.

(10) tsiyaa-tsì yàr dà mukà yi dà shii taa sáa yaa sáa hannuu

'the yelling match that I had with him caused him to sign it' 
mèe ya kaawoo rabaa-ràbànsù?

'what brought about their break up?'11

1.6. Recent loanwords. Loanwords are a good, although not infallible, indication of the synchronic viability of phonological rules. 12 Most loanwords in Hausa that date from an earlier period comply with the phonotactic constraints and the process rules of modern Hausa. Words that were taken into the language with H-L-L tone, for example, generally ended in a short final vowel, e.g. kaar̂ùwà 'prostitute' (< Kanuri) or fứsùnà 'prisoner' (< English). More recently, however, words have started to come into the language ending in L-L and a lfv, e.g.

\section{(11) firaamàrèe}

sakandàrèe

majistàrèe

dì sfansà̃èe $=$ di sfansãrîi

lootàfèe $=$ lootàrîi

àsambulèe 'primary school'

'secondary school'

'magistrate'

'dispensary'

'lottery'

'assembly (e.g. at school)'

These new loanwords that violate LTR all have a similar metrical/rhythmic shape. This is not surprising, since violations of synchronic canonical restrictions often begin with words that are alike in some respect or other. Once these words are fully established and integrated, one can expect phonologically more varied words to enter the language exhibiting the formerly unacceptable (but now possible) L-L lfv pattern.

1.7. Outcome of monophthongization. It is understood that LTR only applies to long monophthongal vowels. Words with final L-L tone ending in a diphthong do not meet the conditions for the rule and thus are expected to remain unchanged, e.g. sàfài 'often', $M$ is sàu (place name). But, what happens when diphthongs monophthongize, as has been an ongoing process in Hausa?13 If LTR were truly functional, one would expect the lexically specific cases of monophthongization to feed the tone raising rule. This is not the case. The

\footnotetext{
${ }^{11}$ This latter sentence was considered only marginally acceptable; the first sentence in (10) was considered just fine.

${ }^{12} \mathrm{~A}$ now classic study of the use of loanword information in evaluating synchronic phonological systems is Hyman [1970].

${ }^{13}$ For a discussion of the phonological interpretation of Hausa diphthongs, see Newman and Salim [1981]; for an instrumental study of the "diphthongs" showing their phonetic realization as monophthongs, see Lindau-Webb [1985].
} 
words that had L-L tone when they ended in a diphthong are still L-L even for the many speakers who now pronounce the words with a long monophthong, e.g.

(12) wàatòo (< wàatàu)

'that is to say'

Feeluwèe (< Feeluwài) 'railway'

Kàasàrèe (< Ràasàrài) 'contemptuously'

By contrast with the above, the $\mathrm{LH}$ to $\mathrm{H}$ simplification rule, which is indeed an active rule in Hausa, is fed by dialectal and/or stylistic vowel modifications, e.g. 14
tàusai
( $<$ and $=$ tàusàyii $)$
via *tàusài
'pity'
nau
( $<$ and = nàawa)
via *nàu
'mine' (NW dialects)

1.8. Result of incorporation of the $q$ question morpheme. Interrogative sentences in Hausa, both wh-questions and yes/no questions, are formed, inter alia, by the addition of an overt $q$ morpheme [Newman \& Newman 1981]. This marker consists of length accompanied for some speakers, but not all, 15 by a floating Lo tone that grounds on the preceding syllable, e.g.

(14) yaafìta 'he went out' $+q \rightarrow$ yaafìtáa or yaafìtaa 'did he go out?'

When the $q$ morpheme is added to a word ending in a short final vowel, the vowel lengthens and becomes a long vowel just like any other long vowel in the language. If the final word of the interrogative phrase ends in $L-L$ tone, the vowel lengthening results in a sequence that meets the conditions for LTR. The rule, however, does not apply, e.g.

(15)

kun sàyi gwàdòo?

kanàa són àyàbàa?

an sàki fữsùnàa? 'did you buy a blanket?' (< gwàdo)

'do you want a banana?' (< àyàbà)

'did they release the prisoner?' (< fuŕsùnà)

\footnotetext{
${ }^{14}$ As pointed out in note 3, Leben [1971] treats LH to $\mathrm{H}$ simplification and LTR as rules having exactly the same status; the facts of Hausa suggest otherwise.

${ }^{15}$ The standard grammars and sketches of Hausa all mention the final $\mathrm{LO}$ tone in one manner or another, which suggests that the absence of the Lo tone, now apparently the norm in Kano city, is the result of a relatively recent innovation. Some speakers allow questions both with and without the fall, but with different connotations; many speakers have the fall with wh-questions but not with yes/no questions; and some speakers have a final rise or Hi tone rather than a fall. Question formation in Hausa (especially with regard to tone and intonation) is an area where we clearly still lack basic documentation regarding dialectal and sociolectal variation.
} 
wàa ya saacèe mini àkwàatì? 'who stole my box?' (< àkwàati )

It might be argued that the lengthening in questions is a sentence level intonational-type process that takes place after all phonological rules have been applied and thus should not be expected to feed LTR. Note, however, that Inkelas, Leben, \& Cobler [1987:328] have claimed explicitly with regard to the L tone component of the $q$ morpheme that it "is added to the lexical tier" by a purely local process. 16 They show, for example, that the distinction between the $\mathrm{H}$ tone word $\mathrm{kai}$ 'you (m.sg.)' and the falling tone word kai 'head' is neutralized in questions when the final $\mathrm{L}$ is added, both words appearing as kái. An exactly parallel case of lexical neutralization holds in the case of the addition of the length component, e.g.
a. yanàa shàafe $+q$
$\rightarrow$
'it is wiped'
yanàa shàafee $+q$
'he is wiping'
b. taa ga $B$ àako $+q$
'she saw Bako (proper name)'
taa ga baakoo $+q$
'she saw the stranger'
$\rightarrow \quad$ yanàa shàafee = shàafée
'is it wiped?'
$\rightarrow \quad$ yanàa shàafee $=$ shàafée
'is he wiping?' 17
$\rightarrow \quad$ taa ga $B$ àakoo $=B$ àakóo
'did she see Bako?'
$\rightarrow \quad$ taa ga bàakoo = bàakóo
'did she see the stranger?'

Using the same reasoning provided by Inkelas et al. for tone, it would follow that the addition of the length must also be at the lexical level, a consequence of which is that large numbers of L-L lfv words are thereby created. Thus, in terms of their own analysis of the level at which question formation takes place, LTR fails to function as it is supposed to.

16For reasons that are hard to fathom, Inkelas et al. ignore the simpler analysis of the tone as being part of the $q$ morpheme (they also totally ignore the fact of the lengthening) and choose to call it a "Low boundary tone". Evidence for treating the length and, where present, the associated L tone as a distinct $q$ morpheme and not as an intonational/boundary phenomenon comes from an observation made by Hyman [in press] that in many languages, wh-questions have declarative rather than interrogative intonation. So it is in Hausa that wh-questions do not have the intonational suspension of downdrift and key raising that characterize yes/no questions and yet they do manifest final vowel lengthening and $\mathrm{L}$ tone. However, this difference in opinion over the source of the $\mathrm{L}$ tone has no effect on their analysis once the $\mathrm{L}$ tone is firmly attached to the preceding word.

${ }^{17}$ Hausa does not have extra-long vowels. Thus, when the length is added to a vowel that is already long, it has no effect (nor does it have any effect when it is added to a word ending in a consonant). Interestingly, in Oromo, a Cushitic language of Ethiopia, underlying vowel length distinctions are preserved when length is added in pre-pausal position since short vowels become long while long vowels become extra-long [Lloret 1989]. 
1.9. Implications of the numerous counterexamples for $L T R$. In the above we have presented eight different classes of examples (a few of which could perhaps be collapsed into larger groups) which constitute violations of LTR in Hausa as originally presented. None of the specific examples in and of themselves would necessarily require a rejection of LTR, but taken in the aggregrate, these counterexamples strongly indicate that, whatever LTR is, it is not a synchronically productive phonological process rule. This is not to say that the phonotactic restriction against L-L lfv words is without significance. The fact that the exceptions fall within clearly defined classes can be taken as evidence that the phonotactic statement is fundamentally sound. But, from a present-day synchronic perspective, Hausa has just too many L-L lfv words deriving from a wide variety of sources and processes to continue to believe in the integrity of LTR as an active rule.

\section{Putative Examples of LTR in Action}

Having demonstrated that LTR is not a general, productive phonological rule, as was previously thought, we now need to provide plausible alternative analyses for the morphophonemic alternations that LTR seemed to explain so beautifully. We should make it clear at this point that we do not question the existence of LTR as a historical rule in Hausa. At an earlier period, Hausa almost certainly had basic common nouns with final L-L tone. When the final vowels underwent lengthening - originally it seems that all final vowels were short, except for low vowels in monosyllabic words (see Newman [1979a, 1986b] and Schuh [1984])the tone of these nouns must have shifted to L-H. The few basic nouns such as àbù 'thing' and màce 'woman' which did not lengthen remained with L-L tone. Synchronically, however, one would not want to replicate this process to generate the citation form of nouns since there is no way to know which L-H nouns came from L-L and which were already L-H even before the historical tone raising took place. The question, then, is not whether LTR ever existed in Hausa, but whether it does so at present.18 To this end we turn to some of the key alternations discussed by Leben $[1971,1978]$.

2.1. Tonal polarity in direct object pronouns. Direct object pronouns in Hausa are traditionally described as having "polar tone", i.e. a tone opposite to that of the final tone of the preceding verb, e.g.

(17) naa kaamàa su 'I caught them' vs. naa hàfbee sù 'I shot them'

${ }^{18}$ For purposes of the present paper, we are simply conceding that LTR was operative at an earlier historical period, which we do, in fact, think was so. Russell Schuh [personal communication], on the other hand, even has doubts about LTR as a historical rule. 
Hausaists have long known, however, that with trisyllabic (and quadrisyllabic) grade 1 and grade 4 verbs, forms that are not in the least uncommon in Hausa, the polarity fails to appear, e.g.
(18) naa kałàntaa ta
'I read it'
mun kakkàamaa su
'we caught each of them'
taa ragar̃gàzaa shi
'she smashed it'
sun bincikee ta
'they investigated it'

Using LTR, Leben proposed an ingenious explanation for the tonal anomaly, which went as follows: (a) Trisyllabic grade 1 and grade 4 verbs are postulated lexically as having H-L-L tone and a long final vowel. (We simplify the discussion by focusing on this class; the same rules hold for longer words.) (b) Direct object pronouns, which are specified underlyingly as having polar tone, are assigned a tone opposite to that of the final syllable of the verb. (c) Then LTR applies raising the final $L$ tone of the verb to $H$, thereby destroying the surface polarity, e.g.
* náa káràntàa tax $\rightarrow$ *náa káràntàa tá $\rightarrow$ náa káràntáa tá 'I read it' Polarity LTR

*sún bínci kèe ta $\rightarrow$ *sún bínci kèe tá $\rightarrow$ sún bínci kée tá 'they investigated it' (where $\mathrm{x}$ indicates polar tone and an acute accent indicates $\mathrm{H}$ )

The same type of analysis, in which polarity is explicitly ordered before LTR, also accounts for the $\mathrm{H}$ tone pronoun objects of grade 1 and grade 4 verbs in the imperative, which are presumed by Leben to have L-L imperative tone, e.g.
(20) *kàamàa sưx $\rightarrow$ *kàamàa sú $\rightarrow$ kàamáa sú 'catch them!' Polarity LTR
*rùfèe ta $\rightarrow$ *rùfèe tá $\rightarrow$ rưfée tá 'close it!'

The linguistic cleverness of the analysis nothwithstanding, the real explanation for the anomaly turns out to be otherwise. The simple reason why direct object pronouns of grade 1 and grade 4 verbs have $H$ tone, thereby sometimes violating surface tone polarity, is that they are inherently $\mathrm{H}$ ! The pronouns are invariably $\mathrm{H}$, regardless of the number of syllables of the verb or the tense/aspect in which it occurs. The derivations illustrated in (19) and (20) are elegant, but unnecessary.

The realization that the direct object pronouns of grade 1 and grade 4 verbs inherently have $\mathrm{H}$ tone rather than polar tone immediately solves the problem of the apparent anomalies, but it of course raises the question of how to account for 
the pronouns that occur in other grades. The answer here is that these other pronouns inherently have $\mathrm{L}$ tone. 19 That is, rather than having a single set of direct object pronouns with tone assigned by polarity, Hausa turns out to have two separate object pronoun paradigms [Newman 1979b]. While it may seem uneconomical to postulate two different pronoun sets, it is in fact quite a common phenomenon in other West Chadic languages, where one set is usually more closely bound to the verb stem than the other set. In these other languages, the pronominal paradigms usually differ in vowel quality and/or length as well as tone. Distinct direct object pronoun paradigms can be illustrated by Bole, where, in contrast to Hausa, the use of one direct object paradigm rather than another depends on tense/aspect, not verb class. The "strong" $H$ tone set, which can be compared to the grade 1 object pronouns, occurs as objects of verbs in the perfective, while the "weak" L tone set, which is also used as possessives, occurs as objects of verbs in the subjunctive. Full paradigms are given in (21a) and examples in context in (21b): 20

(21) a. Bole object pronoun sets

Object set in perfective Object set in subjunctive

\begin{tabular}{|c|c|c|}
\hline 1 & naa & nò \\
\hline $2 \mathrm{~m}$ & kaa & $k d$ \\
\hline $2 f$ & shii & shì \\
\hline $3 \mathrm{~m}$ & ni $i$ & $n i$ \\
\hline $3 f$ & taa & tò \\
\hline $1 \mathrm{pl}$ & muu & $m u$ \\
\hline $2 \mathrm{pl}$ & kuu & $k u$ \\
\hline $3 \mathrm{pl}$ & suu & si \\
\hline
\end{tabular}

b. Examples of Bole object pronouns

\begin{tabular}{|c|c|}
\hline 'ǹ ldodi taa wo(o) & 'I asked her' (wo(o) is a perfective marker) \\
\hline do ni lòodee tò & 'let me ask her' \\
\hline isi) basaa naa wo & 'he shot me' \\
\hline kadà bèsee nò & 'lest he shoot me' \\
\hline
\end{tabular}

${ }^{19}$ Alternatively, one might prefer to analyze these pronouns as underlyingly toneless (cf. Pilszczikowa [1969: esp. pp. 16-19]). For purposes of contrasting them with the inherently $H$ tone pronouns, we shall go ahead and treat them as L.

20Bole data are cited as found in Newman [field notes] and Lukas [1970/71-1971/72]. Schuh [n.d.] records slightly different tone variants for the weak object pronouns, but he too has two clearly distinct paradigms. 
In Hausa, paradigmatic leveling took place with the result that the segmental difference between the pronouns was totally lost, leaving only the tone as the vestigial marker of the distinct sets. One should add that the difference between the "strong" $H$ tone and "weak" $L$ tone paradigmatic sets still exists in present-day Hausa in their degree of bondedness to the verb, i.e. evidence for the existence of two sets can be found synchronically as well as comparatively. In its standard form, the imperative in Hausa is characterized by a L-H tone pattern, e.g. tasashi 'get up!', cf. taashi 'to get up'; dàakàtaa 'wait!', cf. daakàtaa 'to wait' (see Jaggar [1982] for a discussion of the imperative and Newman [1986a] for a discussion of right-to-left tone assignment). When followed by a direct object pronoun, grade 1 verbs manifest this L-H pattern on the verb while the pronoun appears with its inherent $\mathrm{H}$ tone e.g.
(22)
kàamaa shi
'catch him!'
cf. sun kaamàa shi
'they caught him'
kàràntaa ta
'read it!'
cf. naa kar̃àntaa ta
'I read it'

With monoverbs and grade 2 verbs, on the other hand, the imperative tone pattern spreads over the verb and the pronoun, the combination being treated as a single phonological word, e.g. 21

(23) jàa shi

hàrbèe ta

sàyèe su

tàimàkèemu 'pull him!' cf. sun jaa shi

'shoot her!' cf. naa hãrbee tà

'buy them!' cf. mun sàyee sù

cf. taa tàimàkee mù 'they pulled him'

'I shot her'

'we bought them'

'she helped us'

If the object pronouns in (22) and (23) were exactly the same set, as has generally been assumed, then their behavior in imperatives should be the same, which it is not. That is, either the L-H pattern should always apply to the verb phrase including the pronoun, giving for example, *kàamàa-ta and sàyèe-ta, or it should only apply to the verb, giving kàmaa ta and *sàyee ta (or perhaps *sàyee ta). Note that even if one postulated the underlying tone of the imperative to be $\mathrm{L}-\mathrm{L}$ as a means of getting a polar $\mathrm{H}$ tone on the grade 1 object pronoun, one would still need to assume a tighter degree of bonding between the grade 2 verb and its pronoun object in order to prevent LTR from applying. That is, if the pronoun direct object of grade 2 verbs were not attached, forms such as hàrbèe,

${ }^{21}$ In keeping with standard orthography, we shall transcribe the verbs and their pronoun objects as separate words even though from a linguistic point of view they might better be written as single words. 
sàyèe, tàimàkè would all end in L-L with a word-final long vowel and thus would automatically have undergone tone raising.

As if the above comparative and structural evidence were not enough, there is also direct evidence in present-day Hausa of object pronouns with intrinsic $\mathrm{H}$ tone rather than the presumed polar tone. Direct objects of grade 5 verbs in Hausa (the $\mathrm{H}-\mathrm{H}-\tilde{r}$ final "causative/efferential" grade) are usually expressed as obliques introduced by the particle dà, e.g. yaa kooyar dà dàalí bai/suu "he taught the students/them' (< kòoyaa 'learn'); sun hawaf̂ dà yaarinyàa/ita à kán kèekè 'they put the girl/her on the bicycle' (< hau 'mount'). In such cases, the pronouns used are independent/disjunctive forms. Some grade 5 verbs also have a special variant ending in -shee that is used with a $L$ tone object pronoun, e.g. yaa saishee tà = yaa sayar dà ita 'he sold it' (< sàyaa 'buy'); taa fisshee shì = taa fid dà shii 'she threw it out' (< fita 'go out'). What is important for the discussion here is that there is a third, less well known, possibility with grade 5 verbs, namely the use of a $\mathrm{H}$ tone pronoun immediately following the all $\mathrm{H}$ tone verb, 22 e.g.

(24) sun hawat ta à kân kèekè

yaa waatsam $m u=$ yaa waatsar̃ dà $m u u$

taa Kulan ni = taa Kulaĩ dà nii 'they put her on the bicycle'

'he deserted us'

'she angered me'

The object pronouns in (24) have to be regarded as intrinsically $H$. If one assumed that they had polar tone underlyingly, there would be no way to derive their surface form since the final tone of the verb is invariably $\mathrm{H}$. It should be emphasized that although this construction is not commonplace in Standard Hausa, it is documented in the major dictionaries and is fully recognized as grammatical by native Hausa speakers. 23 These are thus unambiguous examples of direct object pronouns that synchronically are fully specified as belonging to the $\mathrm{H}$ tone set.

We conclude, then, that the explanation for the tonal behavior of direct object pronouns in Hausa lies in the existence of two tonally distinct paradigms rather than in a single polar tone set with striking exceptions. Since the tone of the object pronouns of grade 1 and grade 4 is consistently $\mathrm{H}$, rather than polar, the appeal to LTR to handle the apparent exceptions to the presumed polarity is now of no import.

${ }^{22}$ The final $-f$ (historically derived from ${ }^{*}-s$ ) of the grade 5 verb form normally assimilates completely to the initial consonant of the following pronoun and often to other abutting consonants as well.

${ }^{23}$ Abdullahi Bature [personal communication], who unhesitatingly accepted the examples in (24) as fully grammatical, characterized them as "village Hausa". 
2.2. Verb tone alternations. Trisyllabic grade 1 verbs manifest two different tone patterns: H-L-L (with a short final vowel) before a direct object noun and H-L-H (with a long final vowel) elsewhere, e.g. 24

naa karàntà littaafi $i$

naa kařàntaa shi

sun raazànà Kànde

Kànde sukà raazànaa

mun daukàkà shùugàbanm ̀े

shưugàbân dà mukà daukàkaa
'I read the book'

'I read it'

'they terrified Kande'

'it was Kande they terrified'

'we honored our leader'

'the leader whom we honored'

Leben's [1971] explanation, which was incorporated by Newman [1973] in an analysis of Hausa verb forms from a diachronic perspective, was that the underlying verb tone was $\mathrm{H}-\mathrm{L}-\mathrm{L}$ and that the observed H-L-H was due to LTR. Leben assumed that the underlying vowel was long and that there was a shortening rule before noun direct objects while Newman postulated the underlying vowel to be short;25 but in either case, once the length of the final vowel was determined, the tonal alternation in pre-noun and pre-pronoun environments automatically fell into place, assuming, that is, that LTR was valid, which doesn't seem to be the case. But if one rejects LTR, how does one account for the alternations that LTR seemed to handle in such a simple and elegant fashion?

The key element in motivating the search for an alternative analysis is the recognition that the above analysis, in which LTR is central, is itself not without a serious flaw. All grade 1 verbs (as well as all secondary verb grades) form

${ }^{24}$ Grade 4 verbs have two variants. One variant behaves exactly like grade 1 , the other does not. To simplify the exposition here, we shall limit our discussion to grade 1.

${ }^{25}$ The idea presented in Newman [1973] that the final vowel of the verb was underlyingly short, contrary to the received viewpoint regarding Hausa verbs, was based primarily on two observations. First was the comparative evidence from other Chadic languages that the pre-noun form of verbs often constituted the underlying form, and second was the synchronic fact that a number of verb classes in Hausa (such as -oo final grade 6 verbs) do not in fact shorten the vowel before a direct object noun while all verbs without exception have a long final vowel (i.e. undergo lengthening) before a pronoun direct object. (See Leben \& Bagari [1975] for a subsequent (and generally unconvincing) attempt to resurrect the idea of an underlying long vowel with pre-noun shortening.) Further evidence of pre-pronoun lengthening as a general process in Hausa is provided by the "verboid" ungo 'take (it)', which, although this has seldom been noted, can take an object pronoun, in which the final vowel is lengthened, e.g. ungoo ta 'take it (f)', ungoo shi 'take it (m)', etc. Here one should also mention the fact that nouns with short final vowels undergo lengthening when possessive pronouns are attached. (This lengthening usually doesn't surface because it is overridden by a later rule that automatically shortens vowels in closed syllables!) For example, $g$ wadd 'blanket', gwaddo-naa 'my blanket'; aku 'parrot', akuu-nai 'his parrot' [NW dialect] (= Standard Hausa à kunsà). 
"weak verbal nouns" (which often translate as English present participles or gerunds) with a suffix -waa (with L-H tone). Consider the following verb stems, as postulated by Leben, with the occurring present participial forms:

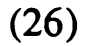

$\begin{array}{ll}\text { *kaamàa } & \text { 'catch' } \\ \text { *dafàa } & \text { 'cook' } \\ \text { *karantàa } & \text { 'read' } \\ \text { *raazànàa } & \text { 'terrify' }\end{array}$

kaamàawaa

dafàawaa

kar̂̀ntâawaa (< kar̃àntaa + 'waa)

raazànâawaa (< raazànaa + iwaa) 'catching'

'cooking'

'reading'

'frightening'

Note that the final vowel of the trisyllabic verbs has a $\mathrm{H}$ tone preceding -waa. Leben [1971:210] accounts for this by postulating a word boundary between the verb and :waa, which allows him to get the occurring verb-final $\mathrm{H}$ tone by means of LTR, e.g. (Leben's schematicization):

(27) kaŕàntàa\# :waa $\rightarrow$ karàntaa\# :waa LTR

Tone Incorporation

The problem here is that there is absolutely no justification within Hausa for the postulated word boundary other than the fact that Leben needs it to make his rules work. ${ }^{26}$ One can of course invent ad hoc boundaries, but given any normal understanding of what we mean by words, suffixes, etc. it is clear to native Hausa speakers as well as to linguists working on the language that =waa in Hausa is a bound suffix that is lexically fused to the word to which it is attached. This being the case, given an input such as *kar̃àntàa-waa, the conditions for LTR are not met, the L-L not being word final, and thus the syllable/tàa/ should not raise. It should be emphasized that for tone raising to take place, LTR requires that the $\mathrm{L}-\mathrm{L}$ lfv sequence be word final. There are many L-L lfv sequences within a word followed by a morpheme boundary, which one can illustrate clearly by citing compounds, e.g. rigàa-kafi 'prevention' (lit. 'precede protective charm'), fàadàa-wuta 'moth' (lit. 'fall into fire'), or dan kòomàa-baaya 'reactionary' (lit. 'one who returns behind'). Thus LTR turns out to be completely irrelevant in one of the major alternations that was supposed to justify its existence. Even if LTR existed, it would be inapplicable in this case.

The most likely reason why trisyllabic verbs have a $\mathrm{H}$ tone before :waa is that the final vowel is lexically $\mathrm{H}$, contrary to to the earlier assumptions of both Leben and Newman. Leben [1971] needed to have these verbs with a final L tone in order to get $\mathrm{H}$ tone direct object pronouns by a polarity rule, but this we

\footnotetext{
26In Leben and Bagari [1975], there is a long explicit discussion of the :waa forms with reference to weaknesses in Newman's [1973] approach. The fact that their analysis required postulating a word boundary between the verb stem and the :waa suffix was not even mentioned.
} 
now know is unnecessary and incorrect. Newman [1973] postulated these verbs as ending with a final $\mathrm{L}$ tone and a short final vowel because comparative evidence suggested that the underlying form should be equated with the actually occurring pre-direct object noun form and because synchronic evidence indicated that there was no automatic vowel shortening rule before noun direct objects. But in this analysis the tone of commonly occurring trisyllabic stems with =waa was also left unexplained. If, on the other hand, one takes H-L-H with a short final vowel as the underlying canonical shape for grade 1 trisyllabic verbs, 27 then everything falls into place. Before pronoun objects, the final $\mathrm{H}$ tone vowel lengthens, as is fully regular before pronoun objects. No tone raising is needed. When -waa is suffixed to a verb, it too is added to a syllable that is already $\mathrm{H}$. The vowel length, which has always been ascribed to the verb, is really part of the suffix. Like the floating tone, the length attaches to the preceding vowel, but morphologically it belongs to the suffix, i.e. the suffix should really be represented as - ? waa, 28 e.g.

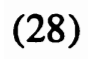

$$
\begin{array}{ll}
\text { *kar̃ànta + -?waa } & \rightarrow \text { kar̃àntâawaa } \\
\text { *raazàna + -?waa } & \rightarrow \text { raazànâawaa } \\
\text { yaa *kar̃ànta shi } & \rightarrow \text { yaa kar̃àntaa shi } \\
\text { sun*raazàna ta } & \rightarrow \text { sun raazànaa ta }
\end{array}
$$

'reading'
'terrifying'
'he read it'
'they terrified her'

It follows necessarily that the H-L-L verb pattern before noun direct objects must be due to a tone change. While all the details are not certain, the tone change would seem to represent weakening of an unstressed light syllable. (It should be

27This abstract underlying form never surfaces as such_-ither the final vowel will be lengthened or the final tone will drop. But this degree of abstractness was also true of Leben's underlying verb form, which was postulated with a non-occurring long final vowel with final $L-L$ tone. The suggestion that trisyllabic grade 1 verbs are underlyingly $\mathrm{H}-\mathrm{L}-\mathrm{H}$ with a short final vowel-a radical proposal that Jaggar does not support-comes out of a new model of the Hausa verbal system being developed by Newman. Elements of this system were presented at a Hausafest held at Stanford University in December, 1989.)

${ }^{28}$ Historically the length with the $L$ tone represents a lost vowel, i.e. the original form of the suffix was not -CV but -VCV. If the suffix is added to a grade 5 verb form ending in a consonant, e.g. kooyalwas 'teaching', or a grade 7 verb ending in -u, e.g. tararuwaa 'meeting', the length cannot be attached and is dropped. (Hausa does not have long /u/ before /w/ nor long /i/ before /y/.) If the syllable preceding the suffix is light, as in the case of $u$-final verbs where the / $u /$ does not lengthen, the tone cannot be attached and is dropped since Hausa does not allow contour tones on light syllables. An alternative explanation for the lack of a long/uu/ and falling tone in grade 7 forms such as tàruwaa has been proposed by Gouffé [1982]. According to his analysis, tiaruwaa (and other such forms) does not contain the suffix : waa, as has always been thought, but rather contains a verbal noun suffix $-a a$ (the same used with grade 3 verbs), which is connected to the grade 7 stem by means of an epenthetic glide / w/, i.e. taaruwaa $<$ talaru-w-aa. Synchronically there seems no way to choose between Gouffé's analysis and the more traditional one; ultimately one would hope that historical/comparative data would provide a clear answer. 
pointed out that H-L-H words with a short final vowel are extremely uncommon in Hausa.) For example,
yaa *kar̃ànta littaafìi $\rightarrow$ yaa kaŕàntà littaafìi
sun *raazàna Kànde $\rightarrow$ sun raazànà Kànde
'he read the book'
'they terrified Kande'

In short, there is nothing in the Hausa verbal system that requires or justifies LTR as a synchronic rule!

2.3. Pre-genitive vowel insertion. While most Hausa words end in a vowel, the language does have a small number of consonant-final words, mostly loanwords from Arabic and English or French. In genitive constructions, where a linker, $-n$ (masculine and plural) or $-t / \tilde{r}$ (feminine), is required, the linker is connected to preceding consonant-final nouns either by use of a deictic particle ( $d i$ in Nigeria, $k i$ in Niger) or by means of a postthetic vowel $-i i$ (in a few cases - $u u$ ), e.g. kànànzî́r 'kerosene', kànànzî́r dîn zaamànii 'modern-day kerosene' (lit. 'kerosene of modem time'); bàabứ 'motorcycle', bàabur̃i i-naa = bàabuŕ dii-naa 'my motorcycle'; làadán 'muezzin', làadaani -nmù 'our muezzin'. The matter of LTR arises in the context of consonant-final nouns with H-L tone such as teebur $\tilde{r}$ 'table' or oofis 'office'. With nouns of this shape, the vowel inserted before the genitive linker has $\mathrm{H}$ tone as opposed to the previous examples where the tone was L, e.g. teebữii-naa 'my table', oofi shi-nsà 'his office', Kaamùsu-n laar̃abcii 'an Arabic dictionary'. Leben's [1971:206ff; 1978:207ff] explanation is that underlyingly the postthetic vowel is the same in all cases, namely toneless, its tonal specification being provided by spreading from the immediately preceding tone. According to this analysis, the $\mathrm{H}$ tone - $\mathrm{ii}$ that one sees, for example, in teeburii is a surface phenomenon that results automatically from LTR. Shortening of the postthetic $-i i$ in closed syllables is understood to be a late rule that applies after LTR. The following illustrates the presumed derivation:

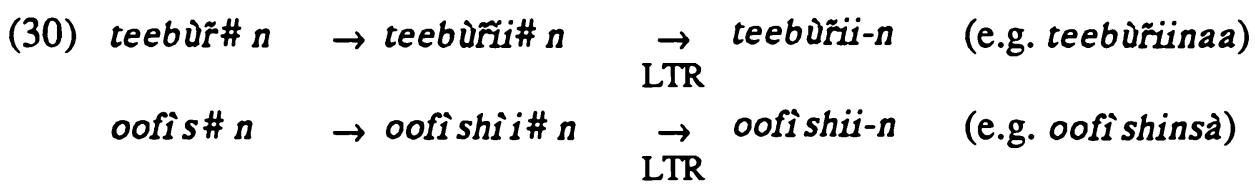

Kaamùs \# $n \rightarrow$ Kaamùsùu \# $n \rightarrow$ Kaamùsuu-n (e.g. Kaamusun laarabcii)

One objection that could be raised against this analysis is that it requires that one postulate a word boundary between nouns and the genitive linker, which seems counterintuitive. But, even if one were to accept this claim for the sake of discussion, the analysis doesn't work. The fact is that all vowels in Hausa are 
long (either inherently long or lengthened) before the linker (cf. Schuh [1977:74]). This statement, being exceptionless, necessarily also applies to nouns that lexically end in L-L and have a short final vowel. If the analysis presented above were correct, such L-L words would meet the condition for LTR and would automatically raise the final tone in the genitive to $\mathrm{H}$. This they do not do, e.g.

\begin{tabular}{|c|c|c|c|c|c|}
\hline (31) gwàdò\# n & $\overrightarrow{\text { Lengthening }}$ & gwàdð̀o \#n & $\overrightarrow{\mathrm{LTR}}$ & ${ }^{*}$ gwàdoo-n & $\begin{array}{l}\text { (cf. gwàddonaa } \\
\text { 'my blanket') }\end{array}$ \\
\hline àkwàatì \#n & $\rightarrow$ & àkwàatìi $n$ & $\rightarrow$ & *àkwàatii-n & $\begin{array}{l}\text { (cf. àkwàatin Karfèe } \\
\text { 'metal box') }\end{array}$ \\
\hline$\tilde{r} s u_{t}$ & $\rightarrow$ & fữsùnàa \#n & $\rightarrow$ & ${ }^{*}$ fursùnaa-n & $\begin{array}{l}\text { (cf. fuŕsùnànmù } \\
\text { 'our prisoner') }\end{array}$ \\
\hline
\end{tabular}

The examples in (31) demonstrate conclusively that the derivations presented in (30) are invalid and cannot qualify as evidence in support of LTR. How then does one account for the difference in tone of the final -ii in làadaanii 'muezzin', for example, as opposed to teeburrii 'table'? One possibility is that the -ii is not an independent suffix, but rather an optional anaptyctic attachment to these words, whose tone pattern is inherently L-H-L or H-L-(H). In support of this one should note (a) that these words can in fact be pronounced with the final vowel in isolation, e.g. làadân = làadaani i and (b) that trisyllabic loanwords ending in /iil (especially Arabic loanwords) most commonly appear with L-H-L or H-L-H tone patterns. Alternatively, one could view the final $-i i$ as an inherently $\mathrm{H}$ suffixal vowel, which, however, has its tone pre-empted by the final tone of the stem when it forms the third syllable of a L-H-L word, e.g.

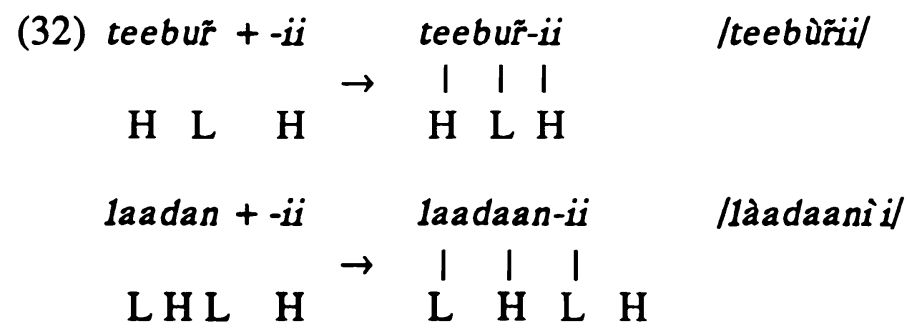

It is not clear at this point which analysis is preferable, but both are straightforward and reasonable and fully consonant with the way Hausa normally works.

2.4. Feminines. Many masculine nouns and adjectives with a final vowel other than /a(a)/ have corresponding feminine forms with final -iyaa or -uwaa. The 
suffix is $\mathrm{L}-\mathrm{H}$ if the masculine has $\mathrm{H}-\mathrm{L}$ tone, $\mathrm{H}-\mathrm{H}$ if the masculine form is $\mathrm{H}-\mathrm{H}$, e.g.

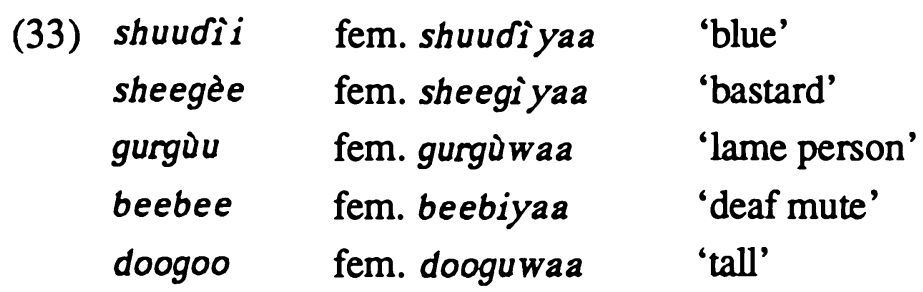

Leben explains the tonal alternation in the feminine forms by positing a single feminine suffix -aa which is attached to and copies the tone of the final vowel of the masculine stem. After vocalic adjustments and glide formation, the details of which do not concern us here, final L-L suffixes (the final vowel being long) are assumed to undergo LTR, thereby producing the observed L-H suffixal tone variants. (To simplify the discussion, we shall illustrate the -iyaa variant only and leave -uwaa aside.) For example,
(34)

$\begin{array}{lll}\text { shuudìi+-àa } \rightarrow \text { shuudiyàa } \underset{\operatorname{LTR}}{\rightarrow} \text { shuudiyaa 'blue, fem.' } \\ \text { sheegèe +-̀̀a } & \rightarrow \text { sheegìyà } \rightarrow \text { sheegiyaa 'bastard, fem.' } \\ \text { (cf. beebee +-aa } & \rightarrow \text { beebiyaa 'deaf mute, fem.') }\end{array}$

In Newman [1979a], it was demonstrated that this analysis could be extended historically to account for the form of the many "feminatives" in Hausa, i.e. nouns that are inherently feminine in form, although not deriving synchronically from masculine counterparts, e.g. tsaamiyaa 'tamarind' ( ${ }^{*}$ tsaame), zuuci yaa 'heart' $\left(<^{*} z u k t i\right)$. The question is whether the derivational process represented in (34), which recapitulates the historical development, is still valid synchronically. There is evidence to suggest that the form -i yaa, with the glide and a fully specified L-H tone, is becoming (or has become) morphologized into a distinct suffix (see Newman [1979a:213-214]). Consider the following masculine/ feminine pairs which cannot be generated simply by adding a suffix $-a a$ and following the derivational sequence postulated in (34):

a. agdolà / agooliyaa bàfaadàa / bàfaadiyaa buulaalàa = buulaaliyaa gàuraakàa / gà uraaki yaa

$$
\begin{aligned}
& \text { 'step-child' } \\
& \text { 'councillor' } \\
& \text { 'shingles' } \\
& \text { 'crownbird' }
\end{aligned}
$$


gimbà / gimbi yaa

gòogarmàa / gòogarmi yaa

ingar̂màa / i ngar̃mi yaa

jàkaadàa/jàkaadi yaa

b. àbookii/àbookiyaa

bàdaadii/bàdaadìya

bàgwaarii / bàgwaariyaa

gàjeeree / gàjeeriyaa 'prince/princess'

'dauntless, persevering person'

'large and strong horse'

'consul, emissary'

'friend'

'bosom friend'

'hard-working person'

(< gwaari 'Gwari')

'short'

The feminine nouns in (35a) cannot be formed from the corresponding masculine stems by adding -aa because there is no motivation for the glide. At an earlier period in the history of Hausa, such words must have been epicene, as is still the case with common words such as sa'àa 'age-mate (male or female)', jiikàa 'grandchild (male or female)'. Forms such as jàkaadi yaa or agooliyaa thus appear to be relatively recent innovations using the new feminine suffix -i yaa. Similarly, the feminine nouns in (35b) can't be derived by adding -aa because the tone is wrong. Leben [1971:215] provides an ingenious explanation for pairs such as àbookii /àbooki yaa by postulating an underlying L-H tone sequence on the final syllable of the masculine form on which a variety of tone rules were then assumed to operate. 29 A much simpler and more direct answer is that abooki yaa, like the other forms cited, is a historically recent creation 30 making use of the now productively available -i yaa suffix. The explanation for the alternation is thus morphological/lexical not phonological.

Given the emergence of -i yaa as a distinct, phonologically fixed morpheme, it is only natural that synchronically generated feminine forms, such as those in (35), should be morphologically reanalyzed as employing this suffix. Thus, while LTR is of essential importance in our linguistic understanding of feminine formations, it is not the case that these feminine derivational and inflectional patterns can be taken as evidence to support the assertion that LTR is still a synchronically active rule.

29It is unfortunate that Leben illustrated his analysis with the incorrect pair beebee/*beebiyaa 'deaf mute' (an error presumably repeated from Abraham's Dictionary). The word beebiyaa in fact has all Hi tones and is a straightforward feminine formative.

30 Originally the stem abookii (with the now frozen suffix - $\mathrm{kir}$ ) could only be used for 'male friend'. 'Female friend' would have been expressed by a form such as abuuyàa or by a different root entirely. 


\section{Conclusion}

Phonotactic restrictions can almost always be rephrased in terms of phonological process rules. Based on the general restriction in Hausa against words ending in L-L with a long final vowel, Leben [1971] proposed a process rule (LTR) whereby the final vowel of words presumed to have that shape in underlying and/or intermediate structure would be raised to $\mathrm{H}$. This rule was then called upon to account for various morphophonemic tonal alternations that occur in Hausa. In this paper we have shown that LTR cannot be accepted as an essentially exceptionless P-rule, as it has been presented, since there are actually large numbers of words of varying types that manifest final L-L with a long final vowel. Some of the counterexamples might be considered more significant than others, but taken as a whole they demonstrate conclusively that LTR does not function as a synchronically active, productive tone rule in Hausa.

We have also analyzed some of the morphotonological alternations discussed by Leben and have shown that better, internally consistent explanations were available without recourse to LTR. For example, we demonstrated that the differing surface tones of direct object pronouns in Hausa came directly from two distinct paradigmatic tone sets (a "strong" $H$ tone set and a "weak" $L$ tone set) rather than from a single set of pronouns with polar tone that required complex tonal manipulation, and that the derivation of feminine forms were derived from a tonally specified suffix -i yaa rather than from a toneless suffix -aa plus sequences of rules that recapitulated the historical development.

As a concept that has forced us to look at tonal restrictions and altemations in a new light, LTR has played a valuable role over the past two decades in Hausa linguistic studies, both synchronic and diachronic. Nevertheless, as the facts have shown, LTR can no longer be accepted as a synchronically functioning rule in Hausa on a par with the truly operative P-rules in the language.

\section{REFERENCES}

Abraham, R.C. 1962. Dictionary of the Hausa Language. 2nd ed. London: University of London Press.

Bargery, G. P. 1934. A Hausa-English Dictionary. London: Oxford University Press.

Carnochan, Jack. 1951. "A study of quantity in Hausa." BSOAS 13:1032-1044.

Camochan, Jack. 1952. "Glottalization in Hausa." Transactions of the Philological Society, pp. 78-109. 
Gouffé, Claude. 1965. "La lexicographie du haoussa et le préalable phonologique." Journal of African Languages 4:191-210.

Gouffé, Claude. 1982. "Notes de morpho-syntaxe haoussa. Note no 1 - le nom verbal primaire en -aa du 'degré 7'." Bulletin des Études Africaines de l'Inalco 2(3):97-104.

Hyman, Larry. 1970. "The role of borrowing in the justification of phonological grammars." Studies in African Linguistics 1:1-48.

Hyman, Larry. In press. "The phonology of final glottal stops." In Proceedings of WECOL [Western Conference on Linguistics], CSU, Fresno, 1988.

Inkelas, Sharon, William R. Leben, \& Mark Cobler. 1987. "The phonology of intonation in Hausa." In Joyce McDonough \& Bernadette Plunkett (eds.), Proceedings of NELS 17, pp. 327-341.

Jaggar, Philip J. 1982. "Monoverbal imperative formation in Hausa: a striking case of analogical realignment." Journal of African Languages and Linguistics 4:133-156.

Kiparsky, Paul. 1985. "Some consequences of lexical phonology." Phonology Yearbook 2:85-138.

Leben, William R. 1971. "The morphophonemics of tone in Hausa." In C.-W. Kim and Herbert Stahlke (eds.), Papers in African Linguistics, pp. 201-218. Alberta: Linguistic Research, Inc.

Leben, William R. 1978. "The representation of tone." In Victoria Fromkin (ed.), Tone: A Linguistic Survey, pp. 177-219. New York: Academic Press.

Leben, William R., \& Dauda M. Bagari. 1975. "A note on the base form of the Hausa verb." Studies in African Linguistics 6:239-248.

Lindau-Webb, Mona. 1985. "Hausa vowels and diphthongs." Studies in African Linguistics 16:161-182.

Lloret, Maria-Rosa. 1989. "Final vowels and grammatical marking in Oromo." In Paul Newman \& Robert D. Botne (eds.), Current Approaches to African Linguistics (vol. 5), pp. 73-84. Dordrecht: Foris Publications.

Lukas, Johannes. 1970/71-1971/72. "Die Personalia und das primäre Verb im Bolanci (Nordnigerien), Mit Beiträgen über das Karekare." Afrika und Übersee 54:237-286; 55:114-139.

McHugh, Brian D. 1981. "Towards a theory of Hausa tone." Unpublished BA thesis, Yale University.

Mijinguini, Abdou. 1986. “À propos des profusatifs en hausa." Les Cahiers $d u$ CEHLTO [Niamey] 4:423-441.

Mohanan, K.P. 1986. The Theory of Lexical Phonology. Dordrecht: Reidel. 
Newman, Paul. 1973. "Grades, vowel-tone classes and extensions in the Hausa verbal system." Studies in African Linguistics 4:297-346.

Newman, Paul. 1979a. "Explaining Hausa feminines." Studies in African Linguistics 10:197-226.

Newman, Paul. 1979b. "The historical development of medial /ee/ and /oo/ in Hausa." Journal of African Languages and Linguistics 1:173-188.

Newman, Paul. 1983. "The efferential (alias 'causative') in Hausa." In Ekkehard Wolff \& Hilke Meyer-Bahlburg (eds.), Studies in Chadic and Afroasiatic Linguistics, pp. 397-418. Hamburg: Helmut Buske.

Newman, Paul. 1986a. "Tone and affixation in Hausa." Studies in African Linguistics 17:249-267.

Newman, Paul. 1986b. "Reduplicated nouns in Hausa." Journal of African Languages and Linguistics 8:115-132.

Newman, Paul, \& Roxana Ma Newman. 1977. Modern Hausa-English Dictionary. Ibadan \& Zaria: University Press (Nigeria).

Newman, Paul, \& Roxana Ma Newman. 1981. "The question morpheme $q$ in Hausa." Afrika und Übersee 64:35-46.

Newman, Paul, \& Bello Ahmad Salim. 1981. "Hausa diphthongs." Lingua 55:101-121.

Newman, Roxana Ma. 1988. "Augmentative adjectives in Hausa." In Graham Furniss \& Philip J. Jaggar (eds.), Studies in Hausa Language and Linguistics. In Honour of F.W. Parsons, pp. 99-116. London: Kegan Paul International.

Parsons, F. W. 1955. "Abstract nouns of sensory quality and their derivatives in Hausa." In J. Lukas (ed.), Afrikanistische Studien, pp. 373-404. Berlin: Akademie-Verlag.

Parsons, F. W. 1960. "The verbal system in Hausa." Afrika und Übersee 44:1-36.

Parsons, F. W. 1963. “The operation of gender in Hausa: stabilizer, dependent nominals and qualifiers." African Language Studies 4:166-207.

Pilszczikowa, Nina. 1969. The Changing Form (Grade 2) of the Verb in Hausa. Warsaw: Państwowe Wydawnictwo Naukowe.

Schuh, Russell G. 1977. "Bade/Ngizim determiner system." Afroasiatic Linguistics 4(3):1-74.

Schuh, Russell G. 1984. "West Chadic vowel correspondences." In James Bynon (ed.), Current Progress in Afro-Asiatic Linguistics, pp. 167-223. (Current Issues in Linguistic Theory, 28.) Amsterdam: John Benjamins.

Schuh, Russell G. n.d. “The Bolanci verbal system.” Unpublished ms., UCLA. 
